\title{
GUTIERREZ, Francisco. Linguagem total: uma pedagogia dos meios de comunicação. Tradução Wladimir Soares. São Paulo: Summus Editorial, 1997.
}

\author{
Magali Seravalli Romboli \\ Mestranda em Educação \\ Universidade Nove de Julho - UNINOVE. \\ Cidade, Estado - País. \\ magali.romboli@uol.com.br
}

Para citar- (ABNT NBR 6023:2018)

ROMBOLI, Magali Seravalli. Resenha. Eccos - Revista Cientifica, São Paulo, n. 59, p. 1-7, e21103, out./dez., 2021. Resenha. GUTIERREZ, Francisco. Linguagem total: uma pedagogia dos meios de comunicação. Tradução Wladimir Soares. São Paulo: Summus Editorial, 1997.

https://doi.org/10.5585/eccos.n59.21103.

Francisco Gutierrez (1928-2016), o autor da obra Linguagem total: uma pedagogia dos meios de comunicação, é um dos pioneiros da associação entre educação e comunicação, que embasou a ciência da Pedagogia da Comunicação, ou dos meios de comunicação. No Brasil, esta Pedagogia foi denominada por alguns, como "Educomunicação".

Gutierrez nasceu na cidade espanhola de Burgos. Licenciado em Educação, dedicou-se, na pós-graduação, à pesquisa de temas como os meios de comunicação e a Pedagogia da Linguagem Total. Foi bolsista do governo francês e estudou na Universidade Complutense de Madri, onde concluiu o doutorado em Pedagogia (1977) para, depois, atravessar o Atlântico e viver a práxis de seu pensamento libertário na América Latina.

O caráter contemporâneo de seus temas ganhou a esfera mundial com a publicação de obras como El lenguaje total (1972), que deu origem a essa versão brasileira Linguagem total: uma pedagogia dos meios de comunicação (1978) e publicada m outros idiomas Total language: a new approach to education (1973), El lenguaje total: vocabulário (1972). Dentre suas obras mais lidas no Brasil, encontra-se Educação como práxis política (1988), também publicada pela Summus. Dentre as mais recentes publicações brasileiras estão: A mediação pedagógica“ (1994), pela Editora Papirus, e a Educação comunitária e economia popular (2021), que foi publicada pela Editora Cortez, após sua morte. 
Ao longo da vida, fez do binômio educação e comunicação um fio condutor de intervenções pedagógicas na Costa Rica, Colômbia, Panamá, Peru e no Brasil.

Na Costa Rica, Francisco Gutierrez descobriu o amor por Cruz Prado Rojas, formada em Direito, mestre em Comunicação e doutora em Educação que, em 1970, teve a coragem de ser dirigente sindical nas plantações de banana da Confederação Geral dos Trabalhadores (CGT). Gutierrez e Cruz Prado, mantiveram um espaço aberto ao diálogo e à reflexão para soluções dos conflitos sociais, em um continente sufocado por golpes militares apoiados por governos dos Estados Unidos. Com livre acesso aos movimentos populares e atuantes na produção científica latino-americana, juntos escreveram teses extraordinárias, destacando-se dentre elas a obra Ecopedagogia e cidadania planetária (2013), publicada no Brasil, pela Cortez.

Em 2003, Gutierrez criou o Doutorado em Educação com especialidade em Mediação Pedagógica, na Universidad de La Salle, em San José, Costa Rica. Durante sua saga pedagógica pelo continente americano, foi inevitável conhecer e compartilhar com Paulo Freire inúmeras investigações sobre a diversidade de percepções educacionais como prática libertária e sustentável. Por este motivo, Francisco Gutierrez foi um dos fundadores do Instituto Paulo Freire (IPF), no Brasil, a partir de uma exigência do próprio Freire aos formuladores do primeiro estatuto da instituição. Como diz um destes formuladores, "Francisco Gutierrez é cota de Paulo Freire na fundação do IPF”.

Embora a edição brasileira do livro Linguagem total: uma pedagogia dos meios de comunicação seja do final da década de 70, do século XX, Gutierrez apresenta uma argumentação científica que é de vanguarda até os dias atuais, ao exemplificar os problemas que os mass media impõem à sociedade e, por consequência, ao ambiente escolar e à cultura dos estudantes e professores. Sobre essa influência midiática na educação, o autor desnuda a problemática com a mesma intensidade, firmeza e radicalidade que apresenta os caminhos estratégicos para que, a partir do domínio das múltiplas linguagens comunicacionais empregadas pelos mass media, professores e estudantes vivam a práxis educacional emancipadora.

A edição brasileira da Summus foi traduzida por Walter Soares, do original em Língua Espanhola, publicado em 1978, pela Editorial Humanitas, na Argentina. Na edição argentina, muitos dos conteúdos dos três primeiros capítulos são transcrições da participação do autor na Mesa Redonda convocada pela Organização das Nações Unidas para a Educação, a Ciência e a Cultura (UNESCO), sobre "Novas inter-relações educacionais", realizada na cidade do México, entre os dias 4 e 9 de dezembro de 1972. Vale observar que, na edição brasileira, o tradutor 
menciona o cenário da primeira abordagem sobre o tema no Simpósio “A Metodologia da Linguagem Total“, ministrado por Gutierrez, em dezembro de 1970, em Bogotá, Colômbia.

A obra é composta por 106 páginas e, logo no prefácio, as “Novas Buscas em Educação", Gutierrez postula os desafios do século XXI, com estudantes mais inquietos e protagonistas, professores sem medo de ter dúvidas, já que a escola ficou cada vez mais aberta e vulnerável à formação da opinião pública pela massificação feita pelos veículos de comunicação, como a imprensa escrita, sonora e audiovisual.

A Editora Summus enalteceu o fato de que a obra de Gutierrez abriu a coleção "Novas Buscas em Educação". Na dedicatória, o autor homenageia mentor intelectual dele e amigo de toda a vida, Antonie Vallet ${ }^{1}$, o pioneiro do conceito "Linguagem Total", nos anos de 1970, na França.

Nos tópicos subsequentes do livro -"Sobre o Autor", a "Introdução" e nos quatro capítulos -, o autor analisa o quanto o advento da televisão gerou mudanças comportamentais e alterou padrões de referências dos alunos, no ambiente escolar e da sociedade em geral. Ao desenvolver a Pedagogia da Comunicação, responsável por uma abordagem pedagógica dos mass media, Gutierrez comprova que é possível dar sentido e significado para a vida escolar do aluno, a partir de propostas alternativas de aprendizagem, quando professores convertem a produção cultural de massa em relações educacionais que buscam propostas de ação. A escola e seus professores passam, assim, a promover processos que auxiliam o aluno a criar, a criticar, a correr riscos, a soltar a imaginação.

O autor busca centrar-se na implementação de um processo pedagógico que possibilite a apropriação crítica e inteligente das mensagens que chegam ao aluno por meio das mais diversas linguagens, sobretudo das chamadas novas tecnologias da comunicação.

No capítulo I, "Os meios de comunicação social fora da escola“, o autor apresenta o cenário originário da alienação em massa, tendo em vista o tempo de exposição de um estudante latino-americano diante de uma tela de televisão se comparado ao tempo que este mesmo aluno passa em sala de aula. A civilização verbal se transmuta para a civilização audiovisual, ao consagrar a onipresença da imagem, carregada de sentidos objetivos, subjetivos e subliminares.

Desde o surgimento da cultura de massa, é importante que educadores se apropriem desses meios comunicacionais para a formação criativa e crítica dos estudantes, dada a velocidade com que essa cultura passou a exercer influência, alterando a percepção e a reação humana diante dos estímulos provocados. O autor alerta, ainda neste primeiro capítulo, para o

${ }^{1}$ Foi mentor intelectual e amigo de toda a vida, com quem Gutierrez desenvolveu o pensamento da Linguagem Total e a Pedagogia da Comunicação. 
fato de que professores de práticas tradicionais não acompanham a velocidade com que a transformação midiática ocorre e, com isso, deixam a escola anacrônica, gerando novos desafios pedagógicos para cada etapa da aprendizagem. Ao ser submetido ao modelo escolar tradicional já ultrapassado, o aluno presencia, ao mesmo tempo, uma mudança cultural universal e, por isso, a escola não pode deixá-lo à margem de sua existência temporal, vivenciada fora do universo escolar.

No capítulo II, “A comunicação e a educação", Gutierrez propõe que a escola seja um centro de comunicação dialógica, posto que, embora o século XX seja conhecido pela insurgência da comunicação de massa, isto não significa que haja comunicação dela para com as pessoas e das pessoas entre si. Para ele, a massificação opõe-se ao compromisso com a realidade e com a naturalidade necessária para a formação da pessoa e da coletividade. $\mathrm{O}$ autor fala de um grande paradoxo que concentra o trabalho atribuído aos educadores que, pela Pedagogia, devem promover o esclarecimento sobre as mudanças dos estudantes diante dos desafios do mundo em que vivem, sem com isso serem impositivos, mesmo que façam uso dos meios da cultura de massa. Para Gutierrez, a aprendizagem é duradoura, enquanto a comunicação de massa é efêmera. Neste sentido, a aula não pode se manter saturada de informação, sem que traga sentido para o aluno; a ele deve ser dada a capacidade de pensar, reagir, criar e exprimir novos olhares.

Ao exemplificar o fato de que um jovem norte-americano passa a saber sobre a Guerra do Vietnã, graças à televisão - isto é, a transmissão da guerra não foi feita em estúdios de cinema e acontece em tempo real -, Francisco Gutierrez já posiciona uma metodologia de abordagem político-pedagógica para usufruto dos meios de comunicação, pois se, de um lado, os mass media promovem massificação, de outro podem conduzir à politização. Se o professor tem domínio sobre estes meios, pode educar a criança em um sistema educacional sem medo da liberdade de expressão.

No capítulo III, a obra discorre, em sete tópicos, sobre "A comunicação total pede uma pedagogia diferente" e chama à atenção para o fato de como as diferentes formas e técnicas de comunicação empregadas pela humanidade, ao longo dos séculos, foram sintetizadas pela linguagem audiovisual. Para decifrar o labirinto dos diferentes meios de comunicação é preciso desenvolver uma Pedagogia desses meios e, consequentemente, é preciso identificar quais são essas linguagens dispostas entre não-verbal, oral e a comunicação escrita e icônica, seus signos e significados.

A abordagem metodológica sobre a linguagem total de Gutierrez reintroduz a pessoa no seu universo de percepções sensoriais, dado que sua existência é individual, coletiva e global. 
A natureza do jovem atual é "sacudida" sensorialmente para trabalhar e se comunicar. Para conviver com os incessantes impactos gerados pelos mass media, a educação deve favorecer as aptidões dos estudantes, mesmo diante das incertezas futuras, porque quando eles têm acesso a uma leitura profunda e repleta de significados, são mais engajados em encontrar caminhos para a autorrealização.

Para o autor, a educação deve libertar-se da prisão à qual foi submetida, quer seja por sua estrutura política, quer seja por seus processos cada vez mais burocráticos.

Gutierrez relembra Piaget ao mencionar que a empatia e a afetividade são reguladoras do processo de aprendizagem e que, na prática educativa, é necessário que se rompa com a relação de dependência entre o professor-informador e o aluno-ouvinte. Para conduzir o leitor às novas fronteiras dessa comunicação dialética e dialógica entre professor e aluno, Gutierrez inova ao propor caminhos metodológicos por meio do seguinte esquema:

Figura 1 - Esquema de Gutierrez

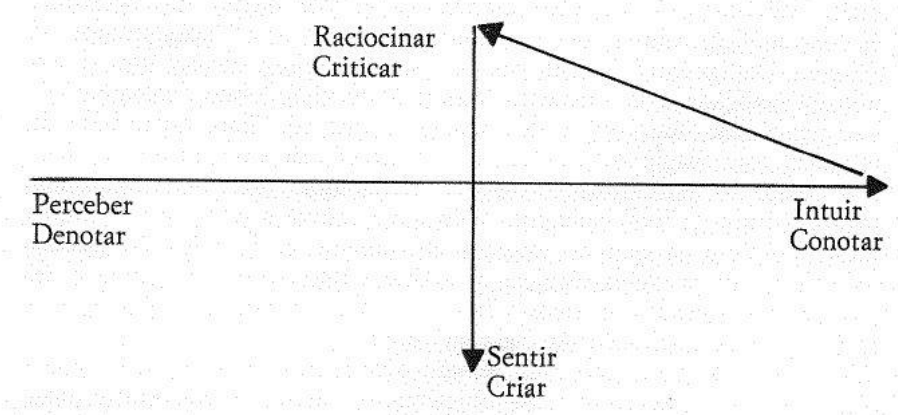

Fonte: GUTIÉRREZ, 1997, p. 59.

A partir deste esquema e, na sua sequência, o autor passa decodificar seu símbolo e significados para incorporação da comunicação no contexto pedagógico, a partir de quatro caminhos:

1. Educação da percepção da leitura denominativa do signo“;

2. "Educação da intuição ou leitura conotativa“;

3. Criticismo ou personalização" e

4. A criatividade“, em que Gutierrez menciona Burrou, Baber, Lewin, Rogers e Freire, ao dizer que, do nascimento à morte, o diálogo é a forma mais genuína de educação. Ainda no mesmo capítulo, o autor enfatiza a importância da dinâmica de grupo entre professores e alunos, associada ao domínio dos meios de comunicação. 
O autor resgata o conceito de Milhiot, visto em Lewin, ao observar uma reação dialógica entre comunicador e receptor, pela abertura de um canal entre os participantes desta comunicação, sem barreiras hierárquicas: toda mensagem é aceita e compartilhada porque é autêntica e gera empatia. Segundo Gutierrez, o trabalho em grupo, isto é, sem a centralidade hierárquica do professor, constitui um dos meios de "desmassificação" da pessoa, a fim de evitar estereótipos que o impeçam de um comprometimento social.

E, por fim, no capítulo IV, "Pontos de apoio da nova metodologia“, o autor dimensiona os meios de comunicação no contexto social escolar, onde a comunicação pode expressar-se sob todas as formas: cinema, pintura, escultura música, fotografia, com a mesma intensidade de um papel e lápis. É essencial que a escola conte com material pedagógico baseado em documentação, textos de autores, fatos históricos, problemas humanos, extraídos também da história atual, posto que a linguagem tradicional traduz o universo objetivo dos adultos, mas não tem igual valor para o mundo das crianças, onde o sonho e a realidade se entrelaçam.

Ao conjugar os caminhos metodológicos para exercício de uma outra prática pedagógica, Gutierrez não faz apologia gratuita da Pedagogia da Linguagem Total. No entanto, alerta para a importância de domínio dessa linguagem por parte dos educadores, para sobrevivência da pessoa reflexiva que, independentemente de seu desejo, já é consumidor de informações massificadas.

Dada a atualidade desta edição, infelizmente só disponível em sebos virtuais, mais do que recomendar, a leitura de Linguagem total: uma pedagogia dos meios de comunicação é obrigatória para todos os profissionais da Educação Básica: pedagogos, professores e gestores escolares, que não conhecem a Pedagogia da Linguagem Total.

Esta contribuição científica fundamenta a formação intelectual para a urgência da atualização docente sobre esta verdadeira "Pedagogia dos Meios de Comunicação", não somente por causa da influência crescente dos meios de comunicação de massa sobre a juventude, mas, também, por causa do domínio que os jovens têm dos instrumentos tecnológicos digitais, a comunicação por vídeo, a conectividade com o mundo por meio de "redes sociais" - e, por isso são considerados como integrantes da chamadas "gerações Y e Z" - que, na maioria das vezes, aprenderam tudo isso fora dos sistemas educacionais formais e que a escola não pode mais continuar desconhecendo olimpicamente esses avanços das novas gerações.

Diante dos parcos recursos governamentais destinados à infraestrutura para o uso de tecnologias da informação e comunicação (TICs) nas escolas e da exclusão digital de professores sem falar que, somado a este cenário, ocorre a resistência de alguns educadores a 
querer dominar as mídias digitais e audiovisuais, a obra Linguagem total: uma pedagogia dos meios de comunicação é leitura atualíssima, por evidenciar caminhos pedagógicos mais atrativos, conscientes e críticos. Nesse contexto, a Linguagem Total de Gutierrez evidencia uma reflexão bem freiriana, ao libertar a escola do desvelamento opressor imposto pela cultura alienante dos mass media. 